\title{
As roças brasileiras, do período colonial à atualidade caracterização histórica e formal de uma categoria tipológica*
}

\author{
Brazilian agricultural fields, from the \\ colonial period to the present \\ historical and formal characterization \\ of a typological category
}

\begin{abstract}
MARCELO ALMEIDA OLIVEIRA Investigador do Centro de Estudos da População Economia e Sociedade - CEPESE/Portugal Analista Ambiental do Instituto Estadual de Florestas - IEF/Minas Gerais/Brasil Instituto Estadual de Florestas / Rodovia Prefeito Américo Gianetti s/ $n^{\circ}$, Edifício Minas, $1^{\circ}$ andar - Bairro Serra Verde Belo Horizonte - MG - CEP: 31.630-900 mmaoout@yahoo.com.br; maoout@gmail.com
\end{abstract}

RESUMO Na atualidade, pouco se indaga a respeito da morfologia do tecido verde dos assentamentos coloniais, sejam eles urbanos ou rurais. A caracterização histórica dos espaços abertos, quanto às respectivas formas e dimensões, possibilita-nos, além da compreensão da disposição de suas diversas partes e elementos estruturantes, o conhecimento de técnicas de cultivo e tradições associadas ao processo de adaptação do colonizador às especifidades do território ocupado. No estudo realizado, priorizamos o entendimento

* Artigo recebido em: 19/02/2011. Aprovado em: 27/11/2011. 
das roças em sua materialidade (benfeitorias, recursos naturais, ambiências e ténicas utilizadas). 0 resultado alcançado por meio deste trabalho também nos leva a perceber a continuidade de saberes relacionados à cultura agrícola, considerada por meio de técnicas autóctones, repassadas de geração em geração por pequenos produtores rurais no Brasil.

Palavras-chave roças, patrimônio paisagístico, atividade agrícola

ABSTRACT Presently, few issues are raised regarding the morphology of green areas in urban or rural colonial settlements. Historical characterization of open spaces, relative to their shapes and dimensions, allows us to know the techniques for cultivation and traditions associated to the colonial's process of adaptation to the specificities of the occupied territory. It also permits us to understand the layout of its different parts and structural elements. In the present study we prioritize the understanding of fields in their materiality (improvements, natural resources, ambiances and techniques used). The result achieved by our study leads us to notice the continuity of knowledge associated to agricultural culture. Such is perceived through the continuity of indigenous techniques, handed down through generations of small rural producers in Brazil.

Keywords farm fields, landscaping heritage, agricultural activity

Trataremos as roças neste artigo como um tipo específico de propriedade, distinto das casas de campo ou chácaras, conhecidas estas como roças e rocinhas, respectivamente, na Bahia e no Pará. As roças que vamos caracterizar constituíam grandes propriedades, igualmente polarizadas pela urbe e destinadas basicamente à produção de mantimentos, sem apelo à prática do recreio, como acontecia em particular nas casas de campo ou nas chácaras.

A natureza percebida nos respectivos domínios podia ser compreendida como hostil e selvagem, noção que estimulava e/ou justificava a derrubada das matas. Para o ouvidor José Xavier Machado Monteiro, responsável pela construção de novas vilas em Porto Seguro, na segunda metade do século XVIII, o corte da vegetação nativa, ao redor dos assentamentos concebidos, numa faixa de "dois tiros" de largura, "proporcionaria arejamento, aumentaria a área de pastagem e afastaria as onças, cobras e mosquitos". ${ }^{1}$

Lisboa. Arquivo Histórico Ultramarino. (AHU). BAHIA-CA, D.9147. "Relação individual do (...) Ouvidor da Capitania de Porto Seguro (...) desde o dia 3 de maio de 1767 athé o fim de julho de 1777". Apud: DELSON, Roberta Marx. Novas vilas para o Brasil-Colônia: planejamento espacial e social no século XVIII. Brasília: Alva/ Ciord, 1997, p.72. 
Os aros verdes ao redor dos aglomerados faziam parte da tradição urbanística adaptada no Brasil, desde os primórdios da colonização. Em termos prático-utilitários, buscava-se garantir a oferta de víveres por meio da disponibilização de solo agrícola na envolvência das cidades. Identificamos esse pensamento em certas fontes documentais, como o conteúdo do Foral de Olinda (1537). ${ }^{2}$ As glebas que desempenhavam essa atividade estavam praticamente inseridas nos tecidos urbanos, o que nos leva a compreendê-las como unidades da mesma estrutura territorial, subordinadas à gestão dos Concelhos. O exame atento dos registros inaugurais sugere a transposição de costumes lusitanos, que influenciaram diretamente o desenho da paisagem, marcado pelo fomento à agricultura. Frente aos indicativos fornecidos por Gabriel Soares de Sousa, as roças deveriam ser compreendidas como os casais, equivalendo às almuinhas, herdades ou quintas rústicas em Portugal. ${ }^{3}$ Distinguiam-se das quintas de recreio por serem terrenos voltados única e exclusivamente à produção, conforme salientado anteriormente. ${ }^{4}$

No período colonial, as terras utilizadas para o plantio das roças poderiam estar ou não vinculadas a glebas destinadas à grande lavoura de monocultura, como as fazendas de engenho de açúcar. ${ }^{5}$ Os terrenos cultivados, em sua maioria, podiam ser devolutos ou pertencer a grandes propriedades. ${ }^{6}$ Esses complexos de produção eram mantidos por mão de obra familiar, de

2 OlIVEIRA, Valéria Maria Agra. (coord.). Projeto Foral de Olinda. Relatório II. Olinda: Prefeitura Municipal de Olinda, Secretaria do Patrimônio e Cultura, 2000; Cf. CAVALCANTI, Vanildo Bezerra. Olinda do Salvador do mundo. Recife: Editora ASA Pernambuco, 1986, p.38-39; Cf. REGIMENTO de Tomé de Souza. In: História administrativa do Brasil. Rio de Janeiro: DASP, v.2, p.223-226. Apud: AZEVEDO, Paulo Ormindo de. Urbanismo de traçado regular nos dois primeiros séculos da colonização brasileira-origens. In: CARITA, Helder e ARAÚJO, Renata. (coord.). Colectânea de estudos: universo urbanístico português 1415-1822. Lisboa: Comissão Nacional para as Comemorações dos Descobrimentos portugueses, 1998, p.56-57.

3 SOUSA, Gabriel Soares de. Tratado descritivo do Brasil em 1587. Recife: Fundação Joaquim Nabuco/Editora Massangana, 2000, p.100-101.

4 Cf. CARAPINHA, Aurora da Conceição Parreira. Da essência do jardim português, v.1. Évora, Universidade de Évora, 1995, p.34-35. (Arquitectura Paisagista e Arte dos Jardins, Ramo de Artes e Técnicas da Paisagem. Tese de Doutorado); Cf. FAUVRELLE, Natália. Quintas do Douro: as arquitecturas do vinho do Porto. Porto: Grupo de Estudos de História da Viticultura Duriense e do Vinho do Porto (GEHVID), 2001, p.21-22. (Cadernos da Revista Douro - Estudos \& Documentos).

5 Os pequenos produtores, conhecidos como roceiros, no período colonial, poderiam pertencer ou não ao sistema monocultor dos grandes engenhos. Aqueles cultivadores que não estavam subordinados à grande fazenda trabalhavam por conta própria, como arrendatários; alguns deles possuíam escravos. Esses pequenos produtores abasteciam o mercado local com gêneros de primeira necessidade, como: mandioca, milho, arroz e feijão. LINHARES, Maria Yedda Leite e SILVA, Francisco Carlos Teixeira da. Os alimentos que fizeram o Brasil. In: CAMPOS, Ana Cristina e CLÉCIA, Maylena. (coord.). Terra e alimento: panorama dos 500 anos de agricultura no Brasil. Brasília: Embrapa, 2000, p.55-56.

6 BACELAR, Carlos de Almeida Prado. Roça. In: SILVA, Maria Beatriz Nizza da. (coord.) Dicionário da história da colonização portuguesa no Brasil. Lisboa/São Paulo: Editorial Verbo, 1994, p.722-723. 
agregados e/ou por reduzido número de escravos roceiros, encarregados do fabrico de mantimentos. ${ }^{7}$

Os pequenos agricultores, ao exaurirem o potencial agrícola de um determinado sítio, sempre abriam novas frentes de trabalho, em locais de solos férteis, geralmente no interior das matas. Ao longo do período colonial e mesmo após a Independência, até o início do século XX, essa categoria de espaço foi essencial para ativar a economia mercantil e abastecer núcleos urbanos e rurais, como é feito até hoje em regiões menos populosas do país.

Para reforçar o que ficou assinalado, mencionamos algumas assertivas sobre o entendimento da tipologia estudada. Gaspar Barleus, no século XVII, salientou, em seus escritos, que as roças eram propriedades rústicas, localizadas nos campos. Forneciam mandioca, matéria-prima para o preparo da farinha, que equivalia ao pão. ${ }^{8}$ Raphael Bluteau, além de considerar a importância da planta, atentou ainda para o processo do preparo da terra ou do roçado, compreendendo a limpeza da gleba, o corte das árvores, a queima da lenha e o tipo de cultura realizada. ${ }^{9}$

O citado procedimento abrangia o quadro da agricultura desenvolvida na vizinhança das matas e dos povoados, destacando-se ali o cultivo do algodão, do amendoim, do anil, do arroz, do café, da cana-de-açúcar, do feijão, da pimenta, do milho, do tabaco, do urucum e de diversas frutas, sobressaindo-se as bananas e laranjas, além do plantio de vários legumes. ${ }^{10} \mathrm{Em}$ grande parte dos textos lidos, a palavra roça é tida como um brasileirismo, sendo o responsável por seu cultivo o lavrador ou o roceiro, também denominado caipira,

7 GOMES, Flávio dos Santos. A hidra e os pântanos: mocambos, quilombos e comunidades de fugitivos no Brasil, (séculos XVII-XIX). São Paulo: UNESP/Polis, 2005, p.83; LINHARES, Maria Yedda Leite e SILVA, Francisco Carlos Teixeira da. Os alimentos que fizeram o Brasil, p.55-56; SILVA, Maria Beatriz Nizza da. História da família no Brasil colonial. Rio de Janeiro: Nova Fronteira, 1998, p.106-107.

8 BARLEUS, Gaspar. História dos feitos recentemente praticados durante oito anos no Brasil e noutras partes sob o governo do ilustríssimo João Maurício Conde de Nassau etc, ora governador de Wesel. Recife: Fundação de Cultura Cidade do Recife, 1980, p.72.

9 BLUTEAU, Padre dom Raphael. Vocabulario portuguez e latino. Lisboa: Officina de Pascoal da Sylva, 1720, v.VII, p.350.

10 CONSTANCIO, Francisco Solano. Novo dicionário crítico e etymológico da língua portuguesa. Paris: Ângelo Francisco Carneiro (editor), 1863, p.859; SILVA, António de Moraes. Dicionário da língua portuguesa. Lisboa: Impressão Régia, 1831, t.II, p.659; VIEIRA, Domingos, Frei. Grande dicionário portuguez ou thesouro da língua portuguesa. Porto: E. Chardron e Bartholomeu H. de Moraes, 1874, v.5, p.317.

Para se ter noção sobre a variedade de espécies produzidas nas roças e em outros tipos de espaços abertos, no período colonial anterior ao século XVIII, é necessário conferir fontes clássicas como: BRANDÃO, Ambrósio Fernandes. Diálogos das grandezas do Brasil. $3^{\mathrm{a} e d}$. integral, segundo apógrafo de Leiden. Recife: Fundação Joaquim Nabuco/Editora Massangana, 1997. (Texto original datado do segundo semestre de 1618). Com relação a esse assunto, verificar também o conteúdo da seguinte referência em ZERON, Carlos Alberto. (org.) Equipamentos, usos e costumes da Casa Brasileira. São Paulo: Museu da Casa Brasileira, 2000. 
capiau, matuto, tabaréu ou vazanteiro, ${ }^{11}$ designações que eram com frequência adotadas no sentido pejorativo, no intuito de acentuar as diferenças entre "a civilização das grandes cidades e a simplicidade dos homens do campo", ${ }^{12}$ tomados como pessoas acomodadas e grosseiras. ${ }^{13}$

Contudo, os limites entre os dois mundos, o rural e o urbano, eram bastante tênues e por demais imprecisos. Os relatos de viajantes europeus, escritos a partir de extensas jornadas em território colonial, durante o século XIX, são fontes de conhecimento da estreita ligação entre o campo e a cidade, percebida através de costumes populares e do próprio desenho da paisagem. Em Goiás, Minas Gerais e São Paulo, Auguste de Saint-Hilaire (1779-1853) observou que as vilas e pequenas cidades tornavam-se movimentadas, particularmente, nos domingos e dias santos, quando recebiam a visita de senhores do campo e suas famílias. Era comum manterem uma segunda residência no meio urbano, onde cuidavam de interesses pessoais vinculados à venda de mercadorias produzidas em suas propriedades. ${ }^{14}$

Em determinadas circunstâncias, os deslocamentos efetuados entre as roças e os povoamentos certamente não ultrapassavam o raio de duas léguas, cerca de 13.200 metros. A partir daí, surgiam as primeiras fazendas ou latifúndios e as ocupações rareavam, conforme registros estabelecidos por Auguste de Saint-Hilaire. ${ }^{15}$ A zona de influência dos espaços urbanos, na maioria das vezes, abrangia a referida distância, fato evidenciado por Gabriel Soares de Sousa ao tratar dos cultivos na envolvência do antigo núcleo de Salvador. ${ }^{16}$ No

11 SOUZA, Bernardino José de. Dicionário da terra e da gente do Brasil: onomástica geral da geografia brasileira. Belo Horizonte: Itatiaia, 2004, p.281. (Primeira edição: 1910).

12 Para os viajantes estrangeiros que visitaram ou permaneceram no Brasil, durante o século XIX, havia traços peculiares que distinguiam os habitantes do interior e os habitantes das vilas e das cidades. Os moradores dos grandes centros urbanos daquela época eram influenciados por modismos europeus, fato reconhecido por meio da adoção de costumes importados. Isso era notado como civilidade, segundo o olhar dos estrangeiros. Nesse contexto, aqueles que não convivinham com a urbanidade eram com frequência alvo de críticas e preconceitos. Nos relatos dos viajantes desse período, os pequenos agricultores foram percebidos como pessoas rudes. Cf. SPIX, Johann Baptist von e MARTIUS, Carl Friedrich Philipp von. Viagem pelo Brasil. Rio de Janeiro: Imprensa Nacional, 1938, t.III, p.18-21. (Edição alemã: 1823).

13 Cf. DEBRET, Jean Baptiste. Viagem pitoresca e histórica ao Brasil. Belo Horizonte/São Paulo: Itatiaia/ Universidade de São Paulo, 1978, t.I, p.227. (Edição francesa: publicada entre 1834 e 1839).

14 CASAL, Padre Manuel Aires de. Corografia brasílica. Rio de Janeiro: Instituto Nacional do Livro/Imprensa Nacional, 1945-1947, t.I, p.395-396; T.II, p.35. (Impressão Régia feita em 1817); SAINT-HILAIRE, Auguste de. Viagem às nascentes do Rio São Francisco e pela província de Goyaz. São Paulo: Companhia Editora Nacional/ Imprensa Paulista, 1937, t.I, p.238. (Edição francesa: 1847); SAINT-HILAIRE, Auguste de. Viagem à província de São Paulo e resumo das viagens ao Brasil, Província Cisplatina e Missões do Paraguai. São Paulo: Livraria Martins/Empresa Gráfica da Revista dos Tribunais, 1940, p.154 e 274. (Edição francesa: 1851); SPIX, Johann Baptist von; MARTIUS, Carl Friedrich Philipp von. Viagem pelo Brasil, t.III, p.142-143.

15 SAINT-HILAIRE, Auguste de. Viagem pelas províncias do Rio de Janeiro e Minas Gerais. Belo Horizonte/São Paulo: Itatiaia/Universidade de São Paulo, 1975, p.37. (Edição francesa: 1830).

16 SOUSA, Gabriel Soares de. Tratado descritivo do Brasil em 1587, p.100-101. 
caso, as dificuldades usuais de transporte e o estado precário das estradas influenciaram a distribuição, a localização e o tamanho dos terrenos agricultáveis. Na vizinhança das vilas de Cachoeira e São Félix, na Bahia, segundo apreciações feitas por Spix e Martius (1817/1820), capinzais, chácaras, hortas e roças, permaneciam em constante imbricação, criando uma atmosfera de aprazibilidade e fertilidade. ${ }^{17} \mathrm{O}$ conjunto observado era distinto para os visitantes, sendo valorizado em oposição às terras incultas do sertão, caracterizadas pela rusticidade de sua paisagem.

Porém, os roçados não ficavam restritos ao aro das urbes. Foram igualmente notados nos aldeamentos indígenas, assistidos por religiosos, nas franjas dos latifúndios monocultores, sobretudo nos terrenos que não se aproveitavam para o plantio da cana-de-açúcar, nas margens dos cursos hídricos e das estradas, em certos lugares de parada ou permanência, denominados ranchos, sendo ainda encontrados nos assentamentos de escravos fugitivos, designados por mocambos e quilombos. ${ }^{18} \mathrm{~A}$ cultura das roças e dos roçados sempre acompanhou o colonizador no desbravamento dos sertões e das florestas quase intransponíveis. Na maneira como os deslocamentos foram impulsionados, principalmente, por padres missionários e sertanistas, destacava-se a escolha de locais estratégicos, que serviam como pontos de apoio para novas conquistas. Os espaços ocupados, no geral, situavam-se próximos de nascentes e rios, por facilitarem eles a produção de víveres e o transporte de mercadorias e pessoas. ${ }^{19}$ Salientamos que a adoção de procedimento semelhante orientou a implantação de mocambos e suas rancharias nas matas. ${ }^{20} \mathrm{O}$ mesmo princípio norteou o desenvolvimento da atividade agroaçucareira, observada em material cartográfico elaborado na primeira metade do século XVII. ${ }^{21}$ Nas represen-

17 Na envolvência dos aglomerados coloniais, era recorrente a existência de aros verdes compostos por diversos tipos de espaços abertos, que se mostravam distintos em termos espaciais e funcionais. Havia hortas, cercas monásticas, chácaras e roças polarizadas por vilas e cidades. No caso das roças, essas se encontravam mais afastadas dos núcleos urbanos. Apesar das diferenças morfológicas existentes entre as mencionadas parcelas, todas elas eram caracterizadas por serem aprazíveis e férteis. Eram locais que ao mesmo tempo favoreciam o ócio e a produção de víveres. Ao tratar das roças, consideramos que os componentes aprazíveis do espaço eram menos relevantes do que os ligados à geração de gêneros agrícolas. Nos relatos dos viajantes europeus do século XIX, as cercanias eram marcadas por sensações de bem-estar e aprazibilidade, algo semelhante à visão edênica. Cf. SPIX, Johann Baptist von e MARTIUS, Carl Friedrich Philipp von. Viagem pelo Brasil. Rio de Janeiro: Imprensa Nacional, 1938, t.II, p. 270-271. (Edição alemã: 1823).

18 GOMES, Flávio dos Santos. A hidra e os pântanos, p.370-376, 387, 396, 408 e 413.

19 LEITE, Padre Serafim. História da Companhia de Jesus no Brasil: o estabelecimento, século XVI. Lisboa/Rio de Janeiro: Livraria Portugália/Civilização Brasileira, 1938, t.I, p.208-209.

20 GOMES, Flávio dos Santos. A hidra e os pântanos, p.57.

21 Cf. “'Prespectiva. Do Ressife, e Villa, de Olinda'. Original manuscrito que integra o códice 'Rezão do Estado do Brasil', de Diogo de Campos Moreno, c.1616”. In: REIS FILHO, Nestor Goulart. Imagens de vilas e cidades do Brasil colonial. São Paulo: Universidade de São Paulo/Imprensa Oficial do Estado/Fapesp, 2000, p.74 e 327.; Cf. “"Todas as fortificasões do lugar do Recife até a Villa de Olinda (...)'. Original manuscrito de João Teixeira Albernaz do 'Livro que da dá Rezão do Estado do Brasil', de [Diogo Campos Moreno], c.1626”. In: REIS FILHO, 
tações manuscritas, além do registro dos povoamentos e engenhos, ainda são notados anéis verdes, como ressaltado na envolvência do núcleo fundacional de Salvador (1631). ${ }^{22}$

Com relação a essa cidade, a imagem representada nos manuscritos aquarelados refletia o incentivo do governo à tradição portuguesa. Por volta da década de 1570, tomaram-se certas providências que desobrigaram agricultores e/ou lavradores do pagamento de impostos. Certamente, o fato resultou na maior ocupação dos terrenos rurais, arroteados da periferia para o centro do aglomerado. ${ }^{23}$ As medidas estabelecidas resultaram na continuidade do tecido verde no desenho da paisagem, o que permaneceu como característica do lugar até, aproximadamente, a primeira metade dos oitocentos. Mesmo levando-se em conta a ocorrência de fragmentação de antigas propriedades rurais e de sucessivas expansões da malha edificada sobre a zona de interface com o campo, Salvador era apreciada tanto pela existência de quintais, hortas, cercas e chácaras quanto pela ocorrência de roças em sua periferia.

Processo análogo aconteceu no Rio de Janeiro, com o espraiamento do primitivo núcleo, localizado no morro do Castelo. Isso ocasionou a gradual alteração do uso do solo nas cercanias, em zona ocupada por atividade agropecuária de caráter extensivo, que cedeu espaço ao cultivo das roças. As parcelas destinadas ao plantio de cereais, frutas e legumes eram, em sua maioria, arrendadas e pertenciam a fazendas de engenhos (Engenho Velho, Engenho Novo e de São Cristóvão). Nos setecentos, essas glebas passaram a ser ocupadas por chácaras. ${ }^{24}$ Apesar da constante transformação da paisagem, o lugar foi com frequência observado como um grande jardim, desde o século XVI. ${ }^{25}$

0 universo das informações apuradas daqueles documentos, das correspondências, em especial, dos jesuítas, desde que chegaram ao Brasil (1549),

Nestor Goulart. Imagens de vilas e cidades do Brasil colonial, p.74 e 327.

22 No início do século XVII, os pequenos agricultores, responsáveis pelo plantio das roças, já eram citados em relatos da época, juntamente com os lavradores de cana e os senhores de engenho; BRANDÃO, Ambrósio Fernandes. Diálogos das grandezas do Brasil, p.LI; Cf. “Planta da Restitvição da Bahia'. Original manuscrito de João Teixeira Albernaz I, do códice 'Estado do Brasil coligido das mais sertas noticias (...)', Rio de Janeiro, 1631”. In: REIS FILHO, Nestor Goulart. Imagens de vilas e cidades do Brasil colonial, p.27 e 313.

23 LEITE, Padre Serafim. História da Companhia de Jesus no Brasil: o estabelecimento, t.I, p.417.

24 LEITE, Padre Serafim. Fazendas e engenhos jesuitas. Rio de Janeiro: Imprensa Nacional, 1945, p.201-204. (Separata da revista Verbum, t.II, fasc.2, Jun.1945).

25 Cf. Le Vrai Pourtraict de Genere et du Cap de frie par Jqz de Vau de Claye [Jacques de Van de Claye]. Detalhe do original manuscrito da Bibliothèque Nationale, Paris. In: REIS FILHO, Nestor Goulart. Imagens de vilas e cidades do Brasil colonial, p.154-155 e 358. Os lugares ocupados por chácaras, nas cercanias, eram locais destinados ao recreio e à produção. Eram propriedades que possuíam atributos físicos, como: vistas panorâmicas, belos jardins e pomares, água em abundância e matas exuberantes. A natureza percebida nesses locais (fértil, sensual e prazerosa) ganhou tons paradisíacos nos relatos elaborados desde os primórdios da colonização. Os arrabaldes foram referência de moradia e lazer entre os mais abastados, fato observado nas fontes inaugurais, inclusive nos testemunhos de religiosos. 
contribui para o entendimento do tema pesquisado. Dão-nos conta da importância atribuída às roças de mantimentos e aos algodoais, situados nas periferias urbanas. Em Salvador, isso se relacionou com o estabelecimento do Colégio da Bahia, sendo priorizado pela administração. Basta dizer que, em outubro de 1550, o Padre Manoel da Nóbrega tomava posse de sesmaria escolhida, pessoalmente, pelo Governador Tomé de Souza (1549-1553), ficando o lugar conhecido como Água dos Meninos, designação bastante significativa por expressar a ocorrência de boas águas e nascentes no local, além de indicar a finalidade básica do terreno, ligada ao sustento dos meninos gentios que passaram a viver no Colégio. Para tornar a gleba produtiva, cederam-se negros da Guiné, incumbidos do fabrico de sustento, atividade possivelmente aprendida com os ameríndios. ${ }^{26}$ Enquanto os homens permaneciam responsáveis pela caça/pesca e manutenção dos roçados, as mulheres dedicavam-se à manufatura da farinha de mandioca, feita a partir da raiz da planta, vulgarmente conhecida por aipi, aipim, carimã, castelinha, cassava, macaxeira, mandioca-doce, mandioca-mansa, maniva, maniveira, pão-de-pobre, uaipi. ${ }^{27}$

A roça de Água dos Meninos, localizada na parte norte da cidade, era bastante ampla, como as outras duas glebas doadas com o mesmo objetivo, no ano de 1563. Uma delas possuía duas léguas em quadra e a outra, menor, tinha um quarto da citada área. Em ambos os terrenos, assim que o provincial da Companhia de Jesus, o Padre Luiz de Grãa, tomou posse, mandou cortar o mato e plantar bananeiras. ${ }^{28}$ Segundo um congregado da Ordem, que era cozinheiro e hortelão, os frutos do mencionado cultivo eram abundantes durante todo o ano, o que ajudava na subsistência alimentar, motivo pelo qual a espécie considerada encontrava-se bastante difundida na paisagem brasileira. ${ }^{29} \mathrm{O}$ ato de ocupar o solo e aproveitar a fertilidade da terra tinha sentido eminentemente pragmático: "fazer mantimentos e criações para a sustentação do dito Colégio". ${ }^{30}$

26 CASTRO, Fernando Pedreira de. Crônica da Igreja no Brasil: período pré-anchietano 1500-1553. Rio de Janeiro/ São Paulo: Editora ABC/Empresa Gráfica da Revista dos Tribunais, 1938, p.156-161; LEITE, Padre Serafim. História da Companhia de Jesus no Brasil: escritores de N a Z. Rio de Janeiro/Lisboa: Instituto Nacional do Livro/Livraria Civilização Brasileira/Livraria Portugália, 1949, t.IX, p.418; LEITE, Padre Serafim. Cartas dos primeiros jesuitas do Brasil: (1538-1553). São Paulo: Comissão do IV Centenário da Cidade de São Paulo, 1956, v.I, p.196-197.

27 FERREIRA, Aurélio Buarque de Holanda. Novo dicionário Aurélio da língua portuguesa. $3^{\mathrm{a}}$ ed. Curitiba: Positivo, 2004, p.1263.

28 LEITE, Padre Serafim. Monumenta brasiliae IV (1563-1568). Roma: [Monumenta Historica Societatis Ieju], 1960, p.28-29 e 33.

29 LEITE, Padre Serafim. Monumenta brasiliae III (1558-1563). Roma: [Monumenta Historica Societatis Ieju], 1958, p.463.

30 LEITE, Padre Serafim. Monumenta brasiliae IV (1563-1568), p.28-29. 
O tamanho das roças facilitava a obtenção de alimentos, também oriundos da caça e da pesca. Registros do século XVI mostram que já se realizavam colheitas de frutas, legumes e outros víveres, além de serem criados animais domésticos. ${ }^{31}$ As propriedades administradas por religiosos foram organizadas a partir de conhecimentos específicos, resultando na construção de açudes, na distinção e rotação de culturas, na drenagem de zonas alagadiças. ${ }^{32}$

Contudo, a bibliografia pouco esclarece a respeito do desenho adotado no espaço como um todo e raramente informa sobre a área das glebas onde se plantavam as roças. No século $\mathrm{XVI}$, sabe-se, por intermédio de outro registro religioso, do ano de 1564, que a "dada" ou “data" de terra, doada pelo Governador da Capitania de São Paulo, Martim Affonso de Souza, para a Companhia e o Colégio dos Jesuítas, tinha duas léguas em quadra junto à Piratininga, o que gerou protestos de moradores da região, por não lhes ficarem outros terrenos para fazerem suas lavouras, "ali perto da villa". ${ }^{33}$ No geral, tudo leva a crer que a tipologia estudada tinha área aproximada entre $1 / 2$ a 2 léguas em quadra. No entanto, em zonas com maior número de pessoas, as roças eram menores, como aconteceu em Vila Bela (1752), no Mato Grosso, onde foram doadas propriedades com meia légua quadrada. ${ }^{34}$ No início dos oitocentos, John Mawe fala do tamanho de algumas parcelas hortifrutícolas nas cercanias da cidade de São Paulo. As maiores glebas tinham, em média, légua e meia quadrada. ${ }^{35}$ As referidas medidas baseavam-se no antigo sistema sesmeiro de concessão de terras, fundamentado nas Ordenações do Reino, particularmente nas Ordenações Manuelinas do Livro IV. ${ }^{36}$

\section{O universo da produção}

Observamos, na bibliografia consultada, que poucos autores contribuíram, efetivamente, para o conhecimento do espaço das roças. Vários deles enfatizaram assuntos como: abertura de roçados, deslocamentos em zonas

31 LEITE, Padre Serafim. História da Companhia de Jesus no Brasil, t.I, p.417; LEITE, Padre Serafim. Novas cartas jesuíticas: de Nóbrega a Vieira. São Paulo: Companhia Editora Nacional, 1940, p.162; LEITE, Padre Serafim. Cartas dos primeiros jesuitas do Brasil: (1538-1553), v.I, p.47-48.

32 Cf. LEITE, Padre Serafim. Fazendas e engenhos jesuitas, p.201-204.

33 Cf. LEITE, Padre Serafim Monumenta brasiliae IV (1563-1568), p.42-43.

34 DELSON, Roberta Marx. Novas vilas para o Brasil-Colônia, p.31.

35 MAWE, John. Viagens ao interior do Brasil principalmente aos distritos do ouro e dos diamantes. Rio de Janeiro: Zelio Valverde, 1944, p.82. (Edição inglesa: 1812).

36 MARX, Murillo. Cidade no Brasil terra de quem? São Paulo: Edusp, Nobel, 1991, p.103; TEIXEIRA, Manuel C. e VALLA, Margarida. O urbanismo português: séculos XIII-XVIII Portugal-Brasil. Lisboa: Livros Horizonte, 1999, p.219. 
de fronteira agrícola, rendimentos de lavouras, técnicas de cultivo, mas sem estabelecer uma correlação com o desenho das parcelas criadas.

Os lugares orientados para a produção eram tidos, em sua maioria, como arcaicos, ingênuos, pragmáticos, primitivos e utilitários. Os viajantes estrangeiros do século XIX, ao se depararem com o mundo da produção e da rusticidade, consideravam-no expressão da mais pura e encantadora desordem e de miséria, opiniões que não estavam destituídas de juízos de valor. Tratavam as moradias, não raras vezes, como cabanas, choças, choupanas, mocambos, palhoças ou ranchos, devido ao fato de essas construções serem executadas com técnicas rudimentares. $\mathrm{Na}$ atualidade, a busca de conhecimento, em regiões fronteiriças e/ou de ocupação esparsa, faz-nos atentar para a permanência de certas práticas culturais que nos levam a refletir sobre o ordenamento das diversas partes de uma roça.

No conjunto patrimonial estudado, podemos situar primeiramente a sede, cuja edificação é definida por padrões tradicionais de moradia, por técnicas vernáculas, e apresentando-se organizada a partir de concepção simples e em pequenas dimensões, cerca de 5 metros de largura, por 6 a 12 metros de comprimento. ${ }^{37}$ Os materiais empregados espelham o conhecimento e as possibilidades de cada sítio. Nas roças, barro, madeira e palha constituem arcabouço básico para quaisquer obras. Costumeiramente, as habitações são apoiadas no solo por quatro estacas, como ainda se pode ver na Amazônia Brasileira. ${ }^{38}$ No geral, os edifícios localizam-se na contiguidade de caminhos ou estradas, no terço médio das encostas, em terrenos cujos solos são bem drenados. No contexto assinalado, a casa-sede ocupa posição de destaque frente a outras construções, também concentradas no terreiro, que chega a abranger área de até $50 \times 50$ metros, com limites visivelmente tênues. ${ }^{39}$

Não menos importante é a relação estabelecida entre a morada e a presença de recursos hídricos. Os lugares, de preferência ocupados pelas edificações, situam-se na vizinhança de mananciais, cujas águas concorrem para satisfazer as demandas cotidianas nos complexos agrícolas. Em alguns casos, aproveita-se também a água proveniente das chuvas armazenada em cacimbas ou poços, usualmente abastecidos por bicas ou tubulações feitas de taquaras, troncos de embaúba ou de paxiúba, palmeira nativa dos igapós. ${ }^{40}$ Os sistemas hidráulicos, como são criados até hoje, reforçam o aspecto de continuidade,

37 COSTA, Eliza Lozano et al. Casa. In: CUNHA, Manuela Carneiro da e ALMEIDA, Mauro Barbosa de. (orgs.). Enciclopédia da floresta. O Alto Juruá: práticas e conhecimentos das populações. São Paulo: Companhia das Letras, 2002, p.233-241.

38 Cf. MAWE, John. Viagens ao interior do Brasil principalmente aos distritos do ouro e dos diamantes, p.82.

39 COSTA, Eliza Lozano et al. Casa, p.234.

40 Cf. COSTA, Eliza Lozano et al. Casa, p.243; LEMOS, Carlos A.C. Cozinhas, etc.: um estudo sobre as zonas de serviço da casa paulista. São Paulo: Perspectiva, 1976, p.35. 
espontaneidade e irregularidade que caracteriza o conjunto da roça, e na ótica dos viajantes europeus apreciado com admiração, encantamento, espanto e certa dose de preconceito. ${ }^{41}$

Os terreiros, conforme registros realizados na região norte brasileira, mostram-se iluminados, limpos e varridos. Constituem espaços funcionais, marcadamente de serviço, normalmente pontuados por várias construções, dentre elas o jirau, o paiol de mantimentos e os telheiros, sendo ainda destinados à criação de animais domésticos. O local em si estabelece comunicação com a horta, o pomar e a casa de farinha, além de irradiar caminhos que igualmente conduzem a igarapés, ribeiras, roçados e seringais. ${ }^{42} \mathrm{Em}$ outras palavras, os terreiros funcionam como lugares de encontro e dispersão. Os percursos irradiados de tais centros, no interior de cada propriedade, que pode alcançar, em média, 300 hectares por família, ${ }^{43}$ acham-se dipostos em completa sintonia com o meio natural, ao longo das cumeadas, encostas e dos rios, não de maneira alinhada ou regular, mas de modo orgânico.

Na região amazônica do Alto Juruá, por exemplo, os terreiros conservam pequenas hortas, conjugadas com jardins, na contiguidade da moradia. Os canteiros permanecem dispostos na meia-sombra, cercados e protegidos contra o ataque de formigas e ratos e a ação danosa de galinhas e porcos. Em determinadas situações, as culturas são mantidas suspensas do chão, em velhas canoas, erguidas por forquilhas de madeira, ou em caixotes recheados de solo orgânico. Dentre as plantas cultivadas, no geral dispostas de maneira promíscua, destacam-se: os bredos, a cebola, a cebolinha, o coentro, a couve, a hortelã, o hortelão-do-irmão-José, o malvarisco, o mastruço, as onze-horas, a perpétua, a pimenta, o tajá, o tomate.

A área da parcela amanhada pode variar, a depender da necessidade da obtenção de alimento e sobretudo do empenho de quem se dedica a esta atividade. Porém nem toda casa possui uma horta e/ou um jardim. ${ }^{44}$ No mais, sobressai, em certos pontos desses terreiros, a imbricação entre plantas exóticas e nativas, disseminadas de modo aleatório. Notam-se, em tais circunstâncias, espécies como os cafeeiros e as laranjeiras, juntamente com abacateiros, abieiros, açaís, bananeiras, biribás, cacaueiros, cajueiros, jambeiros, mamoeiros, mangueiras, a definirem com os respectivos atributos o citado lugar, mas sem haver o fechamento das copas e a redução da visibilidade ao redor, criando situações de aprazibilidade e continuidade com o espaço envolvente.

41 Cf. SPIX, Johann Baptist von e MARTIUS, Carl Friedrich Philipp von. Viagem pelo Brasil, t.III, p.110-112 e 473477.

42 COSTA, Eliza Lozano et al. Casa, p.246-247.

43 FRANCO, Mariana C. Pantoja et al. Botar roçados. In: CUNHA, Manuela Carneiro da e ALMEIDA, Mauro Barbosa de. (orgs.). Enciclopédia da floresta, p.256.

44 Cf. EMPERAIRE, Laure. Entre paus, palheiras e cipós. In: CUNHA, Manuela Carneiro da e ALMEIDA, Mauro Barbosa de. (orgs.). Enciclopédia da floresta, p.406 e 416; Cf. COSTA, Eliza Lozano et al. Casa, p.245-246. 
Nesse âmbito, a imagem de determinados artifícios, como os caixotes de madeira e as canoas, utilizados em plantios que evitam o contato direto com o chão, leva-nos a pensar na transitoriedade da moradia, num mundo marcado pela produção, onde não se criam raízes ou vínculos duradouros com os lugares. Periodicamente, constroem-se novas casas, à medida que as culturas avançam sobre terrenos descansados e férteis da mata, não necessariamente situados nas proximidades dos antigos assentamentos. Tais mudanças, que acontecem no interior da mesma propriedade, decorrem sobretudo dos ciclos e ritmos produtivos do meio natural. A permanência num determinado espaço pode variar de três a cinco anos, a depender do número de colheitas realizadas nos roçados, principalmente de mandioca. De acordo com a tradição, os deslocamentos ocorrem quando a terra costuma apresentar os primeiros sinais de fadiga, como sucede até hoje na Amazônia brasileira, fato associado ao tipo de manejo do solo, que já era identificado nas primeiras cartas dos jesuítas, no século XVI. ${ }^{45}$ Os cultivos ainda são feitos a partir da prática da coivara, técnica primitiva que consiste no corte da mata e na queima de troncos e galhos de árvores, cujas cinzas são aproveitadas como adubo, o que consequentemente reduz o potencial agrícola nas unidades arroteadas.

Antes de tratarmos dos roçados, devemos situar o pomar propriamente dito. Encontra-se na vizinhança do terreiro. Na faixa em que se acha inserido, observam-se outras intervenções humanas, como os campos ou as pastagens, implantados com o intuito de reforçar o limite em relação à mata. No caso do pomar, disposto a uma pequena distância da moradia, observa-se que em geral ocupa parcela equivalente de 0,5 a 1 hectare, correspondendo a lugares anteriormente utilizados para arrotear mantimentos. ${ }^{46} \mathrm{~A}$ diversidade da vegetação cultivada e a área dessas parcelas variam segundo as condições edafo-climáticas de cada região e a disponibilidade de mão de obra para conservá- las produtivas. Muitas das espécies disseminadas resultam de aclimatações, ora por serem plantas de interesse alimentar, medicinal e ornamental, ora por apresentarem potencial econômico. Os pomares são espaços privilegiados para a prática de experimentos botânicos. Mudas e sementes, por vezes, são difundidas nas relações de permuta entre vizinhos. É opinião corrente, no senso comum, que eles constituem locais amenos, aromáticos, calmos, sombreados e verdejantes, a propiciarem atmosfera de intimidade, encantamento e mistério, pela maneira irregular e promíscua como as fruteiras se encontram

45 Cf COSTA, Eliza Lozano et al. Casa, p.231; LEITE, Padre Serafim. História da Companhia de Jesus no Brasil, t.I, p.178. Nos primórdios da colonização, houve vários experimentos de cultivos que envolveram a disseminação de espécies exóticas e nativas. Nos relatos de religiosos do século XVI, tornam-se evidentes: a cultura da mandioca, a necessidade de pousio e o combate às formigas, assuntos pertinentes ao plantio de roçados.

46 Cf. EMPERAIRE, Laure. Entre paus, palheiras e cipós, p.406. 
distribuídas. Árvores e arbustos contribuem assim para explicitar a dualidade entre lazer e produção.

Levando-se em conta a noção de totalidade espacial que buscamos trabalhar, é imprescindível incluir, na análise elaborada, os espaços de cultivo nas margens dos rios e no interior da mata, que também fazem parte da roça. Vulgarmente, são conhecidos por roçados. Trata-se de pequenas parcelas de terra, o que facilita o pousio ou a regeneração da cobertura vegetal nativa, quando as plantações deixam de ser realizadas e sucede o descanso da terra. Frente às alternativas advindas do tipo de manejo efetuado, é necessário concebermos as roças não como um extenso homogêneo, mas como um grande mosaico de diversas e variadas unidades produtivas, complementares entre si, que ajudam a manutenção do domínio ou a posse da propriedade no território.

Reforçamos que a leitura atenta de fontes contemporâneas, relativas a práticas agrícolas adotadas especialmente na região norte do Brasil, contribui para a compreensão do manejo da roça, à semelhança daquilo que acontecia na maioria das glebas arroteadas, durante o período colonial.

Nesse contexto, relativo à realidade amazônica, "Quando um seringueiro 'coloca' ou 'bota' um roçado, ele pode vendê-lo ou trocá-lo, sendo o valor estimado segundo a quantidade de 'roça' plantada”. ${ }^{47}$ A noção de valor desse patrimônio paisagístico não se restringe à venalidade da terra em si, abrange principalmente as culturas praticadas. Nesse sentido, consideram-se os arbustos e as árvores como "bens de raiz". 48

Compreender a maneira como são escolhidos e abertos os roçados, faz-nos valorizar a lógica produtiva existente nas roças e a organização dos respectivos espaços, assunto pouco notado no conteúdo de relatos históricos. Para entendermos melhor a questão, devemos observar que, no conjunto da grande propriedade, ocorriam simultaneamente várias culturas, em diferentes ciclos ou estágios de desenvolvimento, dipostas em diversos lugares, o que requeria permanente trabalho para conservá-las. A complexidade do tema aumenta de grau, ao tratarmos das espécies vegetais utilizadas, temática considerada na sequência do texto.

De acordo com as práticas de cultivo ainda mantidas por populações autóctones, existem os roçados de terra firme e os de várzea. Os de terra firme, como o nome sugere, são realizados em locais que não estão sujeitos a alagamentos, sendo apropriados para produzir mandioca, ou seja, macaxei-

47 FRANCO, Mariana C. Pantoja et al. Botar roçados, p.249.

48 No universo de quem convive com a terra, as espécies cultivadas são percebidas como resultante de esforços agregados ao longo do tempo, o que as torna diferenciadas em relação àquelas não cultivadas. Daí o valor atribuído aos roçados, considerados como bens de determinado grupo de produtores. Além disso, as culturas praticadas indicam domínio ou posse de um território, fato que reforça o significado conferido aos plantios realizados; COSTA, Eliza Lozano et al. Casa, p.232. 
ra. Conforme a posição que ocupam no relevo, são classificados da seguinte maneira: "ponta ou bico de terra" (cumeadas), "lombo" (linhas divisórias de água entre igarapés), "chapada” (grandes superfícies planas) e "baixo" (terço inferior da encosta). Em sua maioria, os terrenos arroteados costumam receber maior incidência de luz solar pela manhã, além de estarem dispostos na proximidade das ribeiras, onde se lava a macaxeira nas farinhadas. ${ }^{49}$ Por sua vez, os plantios de várzea ou de praia, encontram-se distribuídos nas margens dos rios, em faixas distintas de culturas, sendo organizadas em função das características e da taxa de umidade do solo. ${ }^{50}$ Os gêneros obtidos nessas condições são de ciclo curto, produzidos no período da vazante, destacando-se entre eles o amendoim, o arroz, a batata-doce, o feijão-branco, o jerimum, a melancia, o milho, o tabaco. A fim de possibilitar a colheita de duas safras anuais de mantimentos, é usual conservar numa mesma propriedade o cultivo em parcelas de terra firme e de várzea.

Com referência ao desenho da tipologia analisada, devemos igualmente observar a ocorrência de diferentes estágios de cultura, em particular, da mandioca, que no geral é intrinsecamente associada aos plantios de feijão, milho e tabaco. Para melhor percebermos o complexo produtivo, constituído de um amplo e variado mosaico de parcelas, é necessário considerarmos a existência, em simultâneo, de roçados “novos”, “maduros”, "arrancadores” e "encapoeirados". Segundo o costume ainda mantido na Amazônia, cada família conserva, no mínimo, três pequenas unidades em terra firme, destinadas basicamente à produção de mandioca. ${ }^{51}$ No roçado denominado "novo", a espécie é plantada após o cultivo do milho, que serve como fonte de alimento tanto para o homem quanto para os animais domésticos. ${ }^{52}$

A colheita da macaxeira, dependendo da espécie utilizada, é feita um ano após seu plantio, podendo ser prolongada por mais um ano. Enquanto o solo, em algumas parcelas, descansa ou é preparado para um novo ciclo de produção, em outras, mantém-se em plena colheita, como acontece no roçado "maduro" ou no "arrancador”, que coincidem respectivamente com a fase intermediária e a final do processo de cultivo da mandioca. Na fase do "arrancador", a terra, por vezes, é disposta para mais uma safra, o que é antecedido pela cultura do feijão e do tabaco. Antes que o referido espaço seja novamente ocupado por vegetação autóctone, designada por capoeira, depois de realizada a última coleta da macaxeira, é ainda aproveitado para produzir

49 FRANCO, Mariana C. Pantoja et al. Botar roçados, p.250.

50 FRANCO, Mariana C. Pantoja et al. Botar roçados, p.250-251.

51 FRANCO, Mariana C. Pantoja et al. Botar roçados, p.250-251.

52 FRANCO, Mariana C. Pantoja et al. Botar roçados, p.271-272. 
cana-de-açúcar. 0 encapoeiramento pode levar de dez a vinte anos, quando o solo se encontra suficientemente revigorado para mais um ciclo de cultivos na lavoura. A regeneração da mata é lenta, variando de lugar para lugar. Após vários anos de pousio, somente os habitantes nativos conseguem distinguir, no entremeio da cobertura vegetal, os antigos locais arroteados. ${ }^{53}$ Faz parte do trato na roça manter bem visíveis as parcelas amanhadas, principalmente por meio da demarcação de seus limites, com o plantio de várias espécies, dentre elas: abacateiros, bananeiras, mamoeiros, pés de abacaxi ou ananás, também utilizadas para delinear os caminhos até os roçados. Em fronteiras agrícolas, onde a mata sempre recobra a posse dos terrenos cedidos às lavouras, tais procedimentos tornam-se prudentes. ${ }^{54}$

Em determinadas glebas do Nordeste, onde se observava o uso de técnicas rudimentares de cultivo, tal prática representava uma maneira sutil de individualizar o território e estabelecer o domínio da terra, sem causar rupturas na continuidade do espaço da parcela cultivada. Nas zonas rurais, as cercas de taquara, conjugadas com sebes vivas e valados, tinham o propósito de definir e distinguir locais destinados à produção, sem interferência na permeabilidade do sistema natural ao longo da paisagem, como acontecia em sítios à beira do rio São Francisco. ${ }^{55}$ Mesmo compartimentadas, as glebas permaneciam intrinsecamente articuladas umas às outras.

$\mathrm{Na}$ atualidade, essa condição de continuidade espacial nas roças continua sendo favorecida pela forte presença de componentes ecológicos, especialmente por meio da vegetação nativa. Nos domínios da tipologia estudada, certamente a mata é o lugar onde é mais pujante o poder da natureza, que se mantém através de uma biocenose equilibrada, tornando-se importante fonte de provisão para o homem, além de funcionar como um grande regulador climático.

Aos olhos dos naturalistas e/ou viajantes do século XIX, o contato com as matas, que se apresentavam em espaços bastantes fechados, era balizado por um contínuo e alternado sentimento de espanto e êxtase, que contribuía para transportá-los a um raro e singular estado de alma. A descrição de uma floresta era, com frequência, adjetivada por atributos de abundância, contentamento e mistério, chegando ela a ser temida, pelas sensações de caos e

53 FRANCO, Mariana C. Pantoja et al. Botar roçados, p.252-253.

54 FRANCO, Mariana C. Pantoja et al. Botar roçados, p.253.

55 "Pequenos sítios afastados da povoação [de Joazeiro], estão espalhados à beira do rio [São Francisco], separados uns dos outros por taipais de estacas ou cercas de espinheiros, e são guardados por grandes cães que tornam perigoso o mister do botânico"; SPIX, Johann Baptist von e MARTIUS, Carl Friedrich Philipp von. Viagem pelo Brasil, t.II, p.401. 
estranhamento provocadas pela verticalidade dos fustes arbóreos, pelas copas compactas e pelo imbricamento da massa vegetal, periodicamente minimizado nos roçados por meio do uso de machado e fogo, numa tentativa de estabelecer a ordem através do cultivo. ${ }^{56}$

No entanto, a adoção indiscriminada das citadas práticas resultou na incidência de certos desequilíbrios ecológicos provocados no meio natural, percebidos no Brasil desde o século XVI, sendo mencionados, inclusive, no conteúdo de relatos jesuítas. Com a abertura dos primeiros roçados nas matas, observavam-se de imediato ações danosas de formigas, gafanhotos, lagartos e outras pragas, que causavam estragos irreversíveis nas lavouras. ${ }^{57} \mathrm{Em}$ algumas situações, o problema alcançava proporções desmesuradas. 0 uso incorreto do solo, além de provocar desertificações, erosões e esgotamentos nos terrenos destinados à produção de alimentos, também chegava a afetar a dinâmica da natureza no aro das urbes, resultando em infestações de insetos (carrapatos, cupins, formigas, mosquitos, lagartos), como aconteceu em algumas vilas no sul da Bahia durante o ano de 1758, acarretando a transferência daqueles povoados para outros lugares. ${ }^{58}$

A ocorrência desse fenômeno leva-nos a verificar as diferenças entre os roçados estabelecidos por ameríndios e os que foram criados pelo colonizador. 0 tipo de agricultura praticada por grupos indígenas, no geral, acontecia a partir da abertura de clareiras na mata, onde se conservava a diversidade da flora autóctone, fazendo-se simultaneamente o plantio variado da subsistência alimentar, o que, além de reduzir o impacto da ação do homem sobre o meio natural, também servia como alternativa de controle biológico, para conter a disseminação de infestações e pragas. A lógica predominante, imposta pelo europeu, desconhecia ou negava tais cuidados, o que acabava gerando prejuízos ecológicos na ocupação do solo, conforme comentado anteriormente. Segundo a estratégia adotada, a diversidade foi substituída por cultivos

56 SPIX, Johann Baptist von e MARTIUS, Carl Friedrich Philipp von. Viagem pelo Brasil, t.II, p.327-333; T.III, p.713.

57 ACADEMIA BRASILEIRA. Cartas jesuíticas: cartas avulsas (1550-1568). Rio de Janeiro: Oficina Industrial Gráfica, 1931, p.142; LEITE, Padre Serafim. Novas cartas jesuíticas, p.162; LEITE, Padre Serafim. Cartas dos primeiros jesuitas do Brasil, p.47-48.

58 As fontes escritas possibilitam-nos a verificação de malefícios provocados pela supressão da biodiversidade no meio natural. Durante o processo de colonização, o uso extenuante do solo agrícola, associado à prática da monocultura, resultou em danos ambientais, como: erosões e disseminação de pragas. No caso das pragas, a eliminação de predadores naturais, em zonas contíguas aos aglomerados urbanos, influenciou o aumento de infestações nesses locais, reflexo da ocorrência de desequilíbrios ecológicos. Na atualidade, para exemplificar o citado desajuste, cita-se a presença incômoda de colônias de cupins no núcleo antigo de Olinda (Pernambuco). LINHARES, Maria Yedda Leite e SILVA, Francisco Carlos Teixeira da. A produção de alimentos e suas crises, p.63; Cf. SPIX, Johann Baptist von e MARTIUS, Carl Friedrich Philipp von. Viagem pelo Brasil. Tomo I, p.160162 . 
básicos. 0 grande elenco de plantas conhecido e conservado pelas populações nativas ficou reduzido a um universo limitado de espécies, definido em função de suas respectivas capacidades de adaptação, produção e resistência, processo seletivo que foi efetuado, ao longo do tempo, por meio de sucessivas experiências no campo. Dentre os gêneros alimentícios, considerou-se a mandioca, desde o início do processo da colonização no Brasil, como uma das principais fontes de alimento. ${ }^{59}$

Contudo o conjunto agrário colonial - relativo às propriedades produtivas, em suas diversas modalidades, como: hortas, cercas, chácaras, roças e fazendas - não supria de maneira eficiente e regular as demandas do mercado interno, especialmente de povoados, vilas e cidades. As implicações daí decorrentes, acrescidas de vários outros fatores, como: desequilíbrios climáticos regionais; emprego de escassa mão de obra, destinada ao desenvolvimento da agricultura; existência de especulação na venda de alimentos; imposição de normas e regulamentos instituídos pela Coroa portuguesa, sobressaindo-se a obrigatoriedade do envio de provisões às tropas militares, além da exportação de víveres, serviram para tornar mais grave o quadro de abastecimento alimentar. Em alguns períodos, tal conjuntura resultou em carestias, principalmente durante os séculos XVII e XVIII. ${ }^{60}$ Para conter os surtos de fome, os governos locais tomavam medidas drásticas, o que acabava refletindo-se no plantio das lavouras nos arredores das cidades. ${ }^{61}$ No geral, era frequente a obrigação de se fazerem roças. A medida atingia até mesmo os comerciantes, que relutavam no cumprimento da determinação. ${ }^{62}$

59 LINHARES, Maria Yedda Leite e SILVA, Francisco Carlos Teixeira da. A produção de alimentos e suas crises, p.61.

60 LINHARES, Maria Yedda Leite e SILVA, Francisco Carlos Teixeira da. A produção de alimentos e suas crises, p.62-63 e 65; Cf. HOLTHE, Jan Maurício Oliveira van. Quintais urbanos de Salvador: realidades, usos e vivências no século XIX. Salvador, Faculdade de Arquitetura e Urbanismo da Universidade Federal da Bahia, 2002, p.7881, 86, 89, 92, 96, 100, 172 e 175-177, 180. (Arquitetura e Urbanismo, Dissertação de mestrado).

61 Lisboa. AHU. PARAÍBA-ACL-CU-014, Cx.5, D.416: 1724, Junho, 25, Paraíba. CARTA do capitão-mor da Paraíba, João de Abreu Castel Branco, ao rei D. João V, sobre a difícil situação da capitania, em consequência da seca.

62 Lisboa. Arquivo da Marinha e Ultramar. (AMU). N.1352: 1701, Fevereiro, 27. ALVARÁ obrigando a plantação de mandioca na Capital da Bahia. Apud: ALMEIDA, Eduardo de Castro e. Inventário dos documentos relativos ao Brasil existentes no Archivo da Marinha e Ultramar de Lisboa, t.I, p.90-91; AMU. N.1351: 1754, Novembro, 6, Bahia. PROTESTO de vereador da Câmara da Bahia contra a exportação da farinha de mandioca para a Costa da Mina e Reino de Angola. Apud: ALMEIDA, Eduardo de Castro e. Inventário dos documentos relativos ao Brasil existentes no Archivo da Marinha e Ultramar de Lisboa,t.I, p.89-90; AMU. N.8458: 1771, Julho, 3, Bahia. OFÍCIO do governador Conde de Pavolide para Martinho de Mello e Castro, no qual informa acerca da representação dos comerciantes em que pedem para se lhes dispensar a obrigação de terem roças. Apud: ALMEIDA, Eduardo de Castro e. Inventário dos documentos relativos ao Brasil existentes no Archivo da Marinha e Ultramar de Lisboa, t.II, p.258-259. 


\section{Método tradicional de preparo da terra e cultivo nos roçados}

Buscamos compreender o desenho nos roçados, também, a partir do método de preparo da terra, fundamentado nas seguintes etapas observadas na região amazônica: "broca" da vegetação, derrubada de árvores ou paus, queima de lenha e plantio. ${ }^{63}$

Em linhas gerais, a "broca" diz respeito à retirada da vegetação de pequeno porte. É feita utilizando-se o facão, em terrenos de mata fina ou capoeira nova, e o machado, onde predomina a mata bruta ou grossa. Na sequência do processo, acontece a derrubada das grandes árvores, primeiro daquelas que possuem madeiras menos resistentes, como o cumaru, a samaúma, a sapota, para depois serem colocadas abaixo as espécies de troncos mais grossos e pesados, como o aguano, o bálsamo e o pau-d'arco. 0 madeirame disponibilizado, em tal fase, é empregado de diversas maneiras, inclusive na construção de moradias. A etapa seguinte consiste na queima do material lenhoso não aproveitado, que ocorre no período mais seco do ano. ${ }^{64} \mathrm{~A}$ seguir, é feita uma limpeza no terreno desbastado, para dar início ao ciclo produtivo: "o sucesso da plantação depende tanto de um bom verão, para que o terreno queime bem, como de água para fazer brotar". ${ }^{65}$

Esse método ficou evidenciado na região sudeste do Brasil, durante o século XIX. John Mawe já dizia: “Em grande parte, o êxito da colheita depende desta queimada; se tudo for reduzido a cinzas, espera-se uma boa colheita; se o tempo for mau, as árvores derrubadas ficarão semi-queimadas, neste caso, as provisões são más". ${ }^{66}$ É notório como determinadas crônicas de época espelham a realidade recente. Segundo o mencionado viajante, as roças, de áreas avantajadas, eram mantidas produtivas por meio do uso de métodos primitivos de manejo do solo. 0 que sucedia nas glebas localizadas nas cercanias da cidade de São Paulo, em terrenos de légua e meia quadrada ou mais, ainda ocorre na região Amazônica. De acordo com as narrativas do citado viajante, após atear fogo na "mataria", restavam, em maior ou menor quantidade, ao longo das parcelas a serem arroteadas, troncos e raízes da vegetação abatida, o que trazia dificuldades para o plantio, estabelecido não necessariamente

63 COSTA, Eliza Lozano et al. Casa, p.233-241.

64 COSTA, Eliza Lozano et al. Casa, p.233-241; FRANCO, Mariana C. Pantoja et al. Botar roçados, p.260-261.

65 FRANCO, Mariana C. Pantoja et al. Botar roçados, p.262.

66 O plantio de roçados corresponde a uma sucessão de etapas a serem vencidas ou cumpridas; uma delas é a derrubada da mata em local onde serão produzidos gêneros agrícolas. Na sequência, ocorre o preparo do terreno, o que inclui a queima da vegetação cortada. Essa prática deve acontecer em períodos de estiagem para facilitar a supressão de restos vegetais e garantir, ao máximo, a utilização da parcela a ser arroteada. Na chegada da estação chuvosa, todos esses preparativos devem estar finalizados. Se houver atrasos nas medidas adotadas, as chances de boas colheitas ficarão reduzidas, fato observado e comentado por John Mawe em seus relatos. MAWE, John. Viagens ao interior do Brasil principalmente aos distritos do ouro e dos diamantes, p.82. 
de modo regular ou uniforme, como acontecia na Europa com o uso do arado.

De acordo com os naturalistas Spix e Martius, ${ }^{67}$ o emprego daquele instrumento para amanhar o solo não estava difundido, nem era o mais adequado para lidar com a referida situação, especialmente em zonas ocupadas por extensas matas. Talvez a ferramenta tivesse mais êxito nas planícies da região sul. Ao serem percebidas as particularidades dos diversos lugares, nas várias regiões brasileiras, readaptaram-se técnicas habitualmente difundidas. Era bastante comum o manuseio da enxada, de amplo uso para a capina, a limpeza, o plantio e o semeio da terra, atividades desempenhadas basicamente por mão de obra escrava, no período colonial. Diante do exposto acima, presumimos que a grande maioria dos roçados permanecia num quadro de regularidade com alternâncias, o que acontece até hoje nas glebas voltadas à produção familiar e/ou ao abastecimento de mercados locais.

Exemplificamos a questão descrevendo a maneira como se efetua o cultivo da mandioca, organizado em corredores ou faixas, estabelecidos segundo espaçamentos que levam em conta o passo humano ou a medida do cabo da enxada. Dificilmente, nos pequenos roçados, a regularidade é mantida na íntegra, devido à existência de resíduos de matas e de outros materiais inertes, que se encontram sobre o terreno amanhado. 0 agricultor, com frequência, é obrigado a adotar uma noção de ordem variável, de acordo com as condições de plantio em cada parcela, o que está bem próximo da disposição de caráter irregular. 0 mesmo podemos dizer da cultura de feijão-branco, milho, tabaco.

Quanto ao cultivo do arroz de várzea, feijão-peruano e mamão, as sementes são lançadas a esmo, em solos adequados às respectivas culturas, o que reproduz, de certo modo, o quadro anteriormente apresentado. ${ }^{68}$ Por vezes, a aparência promíscua nas parcelas arroteadas torna-se mais evidente, em função da morfologia de certas plantas, como aquelas que enramam. $\mathrm{Na}$ terra firme, onde é semeado o feijão, não se procede à limpeza do terreno, que é apenas "brocado". Galhos e troncos da massa vegetal remanescente servem de suporte para as leguminosas. ${ }^{69}$ Algo parecido ocorre nos roçados de mandioca, onde se fazem leiras para o cultivo do inhame e/ou do cará, cujas ramadas, ao contrário do que acontece com a batata-doce, não se alastram muito e podem ser razoavelmente orientadas, por meio de pequenas guias ou estacas de madeira, cravadas no solo. ${ }^{70}$ Com referência ao assunto, Maria Graham deixou testemunho da maneira como se procedia ao plantio conjunto de cana-de-açúcar, feijão e milho, na zona rural do Rio de Janeiro.

As canas-de-açúcar são plantadas aqui durante os meses de março, abril,

67 SPIX, Johann Baptist von e MARTIUS, Carl Friedrich Philipp von. Viagem pelo Brasil, t.I, p.160-161.

68 FRANCO, Mariana C. Pantoja et al. Botar roçados, p.254-255, 265.

69 FRANCO, Mariana C. Pantoja et al. Botar roçados, p.265, 283.

70 FRANCO, Mariana C. Pantoja et al. Botar roçados, p.279-280. 
maio, e mesmo junho e julho. Nas filas entre elas, plantam-se pés de milho e de feijão, cujo cultivo é favorável à cana-de-acúcar. 0 feijão é colhido primeiro, quando o solo é mondado, limpo e afrouxado em torno das raízes das canas; em seguida é arrancado o milho, fazendo-se nova mondação e limpeza. Só depois disso o açúcar está bastante alto para ensombrar o terreno e evitar o nascimento de ervas más. ${ }^{71}$

Esse registro demonstra a sabedoria do agricultor que, em diversas circunstâncias, buscava tirar proveito do plantio associado, estabelecido a favor da produção. Além da necessidade de ordenar o cultivo em faixas, tendo em vista a facilidade de seu manejo, era patente o propósito a ser alcançado por meio da cultura conjunta. No caso, o feijão e o milho, pelo fato de serem plantas de ciclo curto e rápido crescimento, possibilitavam maior fertilidade do solo e sua proteção, resultando isso no desenvolvimento da lavoura de cana-de-açúcar. Diante do exemplo apresentado, vemos que quanto maior o convívio do homem num determinado meio maior é sua habilidade para percebê-lo e daí criar facilidades para sua própria adaptação. Na roça, isso significa dizer que o conhecimento prático e o senso de observação da natureza são fundamentais para o estabelecimento de soluções criativas e eficientes, que repercutem no sucesso das atividades agrícolas.

Situamos a questão a partir de duas situações recorrentes, observadas na região Amazônica, tratadas com sabedoria e simplicidade por moradores locais. Uma delas diz respeito à demarcação dos terrenos arroteados na interface com a mata, sem o rompimento da continuidade do espaço, o que é feito por meio do plantio de diversas touceiras de bananeiras, que se adequam bem às zonas sombreadas e de solos com alta taxa de umidade. A outra situação é marcada pelo uso de inseticidas ou remédios naturais, adotados para o controle de pragas que, frequentemente, atacam plantações domésticas.

Quando os pés de milho começam a soltar as suas primeiras espigas, os kaxinawá costumam colocar em um deles diversas folhas de uma planta chamada xinaitê para evitar que largartas as estraguem. Esse inseticida natural é tão eficaz que basta colocá-lo em um pé de milho, estrategicamente localizado no meio do roçado, para proteger todas as espigas do milharal. Processo semelhante é utilizado nas bananeiras, protegidas também por um 'remédio da mata', as folhas do manero. ${ }^{72}$

De acordo com a herança ancestral, admitimos que as técnicas difundidas para lavrar o solo, juntamente com a noção de qualidade de vida, considerada

71 GRAHAM, Maria. Diário de uma viagem ao Brasil. Belo Horizonte/São Paulo: Itatiaia/ Universidade de São Paulo, 1990, p.334. (Edição inglesa: 1842).

72 FRANCO, Mariana C. Pantoja et al. Botar roçados, p.272. 
pelo morador do campo, são fatores condicionantes do desenho das parcelas produtivas. No contexto da roça, a qualidade de vida está intrinsecamente associada à riqueza e à variedade de víveres obtidos em suas diversas unidades: hortas/pomares, terreiros, roçados e matas. Essa noção ainda está relacionada com a fartura proveniente da caça e da pesca, além do extrativismo vegetal, dos criatórios e da colheita periódica de arroz, cana-de-açúcar, feijão, frutos, milho, legumes, tabaco e, sobretudo, de mandioca, matéria-prima para o fabrico de farinha, uma das principais fontes de alimento no meio rural.

O que importa é a produção, a ponto de se manter, numa única gleba, um ou mais roçados, até mesmo antes de ser construída a moradia. 0 tamanho das lavouras varia em função das expectativas desejadas, da mão de obra disponível, do modo de preparo da terra, além do tipo da cultura praticada. No caso do terreno destinado ao plantio da mandioca, pode alcançar, em média, na reserva extrativista do Alto Juruá, uma área de 0,3 a 0,9 hectare, o que abrange cerca de três mil covas ou "paus", sendo tomado o espaçamento de 2 metros quadrados por cova. Como é hábito cuidar, no mínimo, de três roçados no domínio da roça, isso significa que menos de $1 \%$ dos 300 hectares previstos para cada grupo familiar, encontra-se arroteado na citada reserva, algo em torno de 1,8 a 2 hectares. ${ }^{73}$

\section{Elenco vegetal}

No vasto repertório das espécies vegetais encontradas na roça, conforme já mostrado, destaca-se a mandioca que, segundo Luís da Câmara Cascudo, é tida como a "rainha do Brasil". De acordo com esse autor, quando a posse da terra começou a ser feita, no Novo Mundo, nasceu o elogio à sua cultura, o que pode ser verificado no conteúdo de grande parte das crônicas escritas nos séculos XVI e XVII, como nas obras de Ambrósio Fernandes Brandão, André Thevet, Claude d'Abbeville, Fernão Cardim, Frei Vicente do Salvador, Gabriel Soares de Sousa, Hans Staden, Ivo d'Evreux, Jean de Lery, Joan Nieuhof, José de Anchieta, Manoel da Nóbrega, Pero de Magalhães Gandavo. ${ }^{74}$ Até mesmo na Carta inaugural de Pêro Vaz de Caminha está citada a planta cuja raiz servia de alimento a tribos indígenas e que, equivocadamente, foi denominada inhame. ${ }^{75}$

73 FRANCO, Mariana C. Pantoja et al. Botar roçados, p.254-256, 280-281 e 283.

74 Cf. CASCUDO, Luís da Câmara, 1898-1986. História da alimentação no Brasil. São Paulo: Global, 2004 , p.90. (Primeira edição: 1967).

75 AZEVEDO, Ana Maria de e ÁGUAS, Maria Paula Caetano e Neves. (orgs.). CARTA de Pêro Vaz de Caminha a El-Rei D. Manuel sobre o achamento do Brasil. Mira-Sintra: Publicações Europa-América, 2000, p.77, 111. 
Para o colonizador, a mandioca ficou bastante conhecida, principalmente, pela sua alta produtividade. Apresentava ainda a vantagem de seu cultivo ser pouco exigente com relação às condições edafo-climáticas. Além das qualidades mencionadas, era apreciada por sua ampla utilidade, servindo de matéria-prima ao fabrico de diversos tipos de alimentos, sobressaindo a farinha, vulgarmente apelidada de "munição de boca" ou "pão-de-pobre", que bem acondicionada, na palha da bananeira ou em bruacas, matulas e surrões, constituía a ração básica para guerras, ofertas e viagens. ${ }^{76} \mathrm{~A}$ história é rica de detalhes, que nos situam perante o valor atribuído à "manihot utilissima", como ficou celebrizada a mandioca, sendo tratada como um símbolo da culinária colonial, seja na forma de bolo, beiju, caldo, farofa, mingau, papa, pirão, polvilho, seja na sua forma mais primária ou primitiva, como até hoje. ${ }^{77}$

No entanto, pouco se sabe a respeito do grande número de exemplares da referida planta. Temos uma vaga ideia da abrangência do tema a partir das variedades utilizadas nas zonas de fronteira agrícola, particularmente na região Amazônica, que servem de base para a compreensão das roças coloniais. ${ }^{78}$ Essas variedades foram selecionadas para produzir farinha, segundo a consistência e o sabor da polpa, processo que também levou em conta a rentabilidade, o tempo de maturação da raiz e de prorrogação da colheita. Estima-se que somente uma pequena quantidade de exemplares do universo existente, com mais de 100 espécies, encontra-se domesticada, tarefa levada adiante, ao longo do tempo, por comunidades indígenas, o que torna o espaço de suas respectivas roças lugares singulares, do ponto de vista da biodiversidade e do potencial genético. A preservação de um grande número de gramíneas, frutos, raízes e tubérculos certamente está intrinsecamente ligada à manutenção de tradições ancestrais e místicas.

Frente à riqueza botânica conhecida e divulgada a partir das populações nativas, o colonizador teve seu trabalho simplificado na tarefa de selecionar as plantas utilitárias e economicamente mais rentáveis. Na cultura de contato estabelecida com os ameríndios, o português acabou absorvendo costumes alimentares e práticas agrícolas que tiveram rebatimentos diretos na transformação da paisagem, especialmente nas zonas de produção.

Tal assimilação de costumes também contribuiu para a difusão do cultivo de abóboras, amendoins, feijões, além de favorecer o predomínio das roças de mandioca na Amazônia, no litoral do Rio de Janeiro e no Nordeste, e das plantações de milho em terras goianas, mineiras e paulistas, durante o perío-

76 LINHARES, Maria Yedda Leite; SILVA, Francisco Carlos Teixeira da. A produção de alimentos e suas crises, p.50-51.

77 Cf CASCUDO, Luís da Câmara, 1898-1986. História da alimentação no Brasil, p.93-94.

78 FRANCO, Mariana C. Pantoja et al. Botar roçados, p.266-268. 
do colonial. Ao atentarmos para esse quadro, percebemos melhor a ocorrência de uma "geografia alimentar" no Brasil, caracterizada pelo grau de especialização de certas lavouras em diferentes regiões. ${ }^{79}$ Podemos ainda identificar a adoção de legado tecnológico indígena, costumeiramente utilizado para o fabrico de provisões preparadas de maneira artesanal nas casas de farinha, ${ }^{80}$ estrategicamente posicionadas entre os roçados, ao longo de ribeiras, em pontos de fácil acesso, como observado no desenho das parcelas arroteadas, onde usualmente se construíam monjolos ou engenhocas movidas à água. No vasto mundo da roça, além da mandioca, outras produções de origem nativa ou naturalizadas ocuparam lugar de destaque na lavoura brasileira, como o arroz, o feijão e o milho, situação verificada no levantamento realizado pelo vice-rei, $2^{\circ}$ Marquês de Lavradio (1769-1779), feito no ano de $1779 .{ }^{81}$

0 milho, apesar do valor nutritivo, não obteve a mesma evidência da mandioca. Seu cultivo era bastante popular somente em algumas regiões, principalmente, por ser de ciclo curto e alta produtividade. Outro motivo que influenciou a propagação da planta foi sua tolerância a diversos tipos de solo, sendo disseminada nas várzeas, em conjunto com outras culturas. Isso garantia a frequente reposição dos estoques alimentares ao longo dos caminhos, abertos em direção ao povoamento da parte oeste do território brasileiro. Em mãos portuguesas, as variedades conhecidas tiveram significativo uso, visando a manter a escravaria e as criações domésticas, além de serem aproveitadas na culinária, em forma de bolos, canjica e pudim. Contudo, é escassa a bibliografia que trata das espécies, ainda conservadas por algumas populações indígenas. Sabe-se que os Kaxinawá conseguem distinguir sete variedades de milho massa ou paulista e duas de milho duro, além de outros exemplares. ${ }^{82}$

No quadro da alimentação brasileira, o arroz e o feijão constituíram outro pilar da subistência cotidiana, desde os séculos XVII e XVIII. A cultura de arroz encontrava-se particularmente difundida nas várzeas da Amazônia, do Maranhão e no Rio de Janeiro, enquanto o feijão foi levado para as marchas de povoamento no interior, mantendo-se trivial na faixa litorânea, em especial, da Bahia e da região fluminense. ${ }^{83} \mathrm{Na}$ atualidade, os roçados da reserva extrativista do Alto Juruá fornecem indicativos dos exemplares mais valoriza-

79 LINHARES, Maria Yedda Leite e SILVA, Francisco Carlos Teixeira da. A produção de alimentos e suas crises, p.54.

80 POSEY, Darrell. O manejo da floresta secundária. In: RIBEIRO, Berta. Suma etnológica brasileira. Petrópolis: Vozes, 1986, p.173-189.

81 SILVA, Teixeira da e C. Francisco. A morfologia da escassez: política econômica e crises de fome no Brasil. Niterói, UFF, 1991. (História, Tese de doutorado); LINHARES, Maria Yedda Leite e SILVA, Francisco Carlos Teixeira da. A produção de alimentos e suas crises, p.55.

82 FRANCO, Mariana C. Pantoja et al. Botar roçados, p.271-273.

83 LINHARES, Maria Yedda Leite e SILVA, Francisco Carlos Teixeira da. A produção de alimentos e suas crises, p.54. 
dos nos dois tipos de cultivo, desenvolvidos segundo condições específicas da natureza amazônica. ${ }^{84}$

No universo da roça, é a mata que abriga maior diversidade e repertório botânico, seu elenco possibilita tanto o desenvolvimento de tecnologias alternativas e o fomento da indústria extrativista quanto a permanência de costumes ancestrais, relacionados com a construção de casas, com a prática de atividades de lazer, caça e pesca, e certos ritos religiosos. A mata surge como um grande celeiro de plantas que favorece múltiplas aplicações, com o uso de espécies alimentares, medicinais, têxteis, ritualísticas, tintureiras, e mesmo ornamentais, além de contribuir para o enriquecimento da ambiência no complexo existente. ${ }^{85}$

A mata, na roça, como é percebida em fontes referenciais da realidade amazônica, sempre se apresenta rica em alternativas. Por hábito e/ou necessidade, as moradias, como no período colonial, são ainda edificadas utilizando-se basicamente madeira e palha, o que possibilita maior conforto bioclimático a seus moradores. As casas seguem padrões tradicionais, orientados pelo procedimento de selecionar o tipo certo de madeira para cada parte da obra, a começar pelos barrotes e esteios, que devem apresentar durabilidade e resistência. Para realizar a amarração estrutural, executada na cumeeira, no frechal e no piso, conta-se com a flexibilidade de certas espécies arbóreas, algumas palmeiras e várias qualidades de embiras ou enviras, que também servem para efetuar os encaixes. São plantas cujos componentes apresentam alta resistência à tração. Adotam-se outras espécies para as vedações de paredes externas, a construção de escadas e assoalhos, além da cobertura, executada a partir da palha advinda de diversas palmeiras, escolhidas em função do

84 Cf. FRANCO Mariana C. Pantoja et al. Botar roçados, p.271-283; Cf. CASAL, Padre Manuel Aires de. Corografia brasílica. t.II, p.35, 47, 75-76, 83-84, 95-98, 134-135, 159, 183-186, 190, 197, 209, 214-216, 230, $244-245$ e 322; Cf. MAWE, John. Viagens ao interior do Brasil principalmente aos distritos do ouro e dos diamantes, p.8082; Cf. SAINT-HILAIRE, Auguste de. Viagem à província de Santa Catarina (1820). São Paulo: Companhia Editora Nacional, 1936, p.97 e 214-215; Cf. SAINT-HILAIRE, Auguste de. Segunda viagem ao interior do Brasil. Espírito Santo. São Paulo: Companhia Editora Nacional, 1936, p.106 e118-122; Cf. SAINT-HILAIRE, Auguste de. Viagem às nascentes do Rio São Francisco e pela província de Goyaz, t.I, p. 14, 18-21, 23-24, 31-34 e 36-37; T.II. p.54-55; Cf. SAINT-HILAIRE, Auguste de. Viagem à província de São Paulo e resumo das viagens ao Brasil, Provincia Cisplatina e Missões do Paraguai, p.154, 169, 202-203, 223, 249-252, 274 e 301; Cf. SPIX, Johann Baptist von e MARTIUS Carl Friedrich Philipp von. Viagem pelo Brasil, t.I, 103-106, 146, 211, 256-257, 271, 275-276, 279 e 293-295; T.II, p.140-141, 152-153, 187-188, 194-195, 261, 268, 274, 303, 312-313, 333, 340, 350352, 375-376, 387, 467-468 e 547-551; T.III, 25-26, 68-69, 165-166 e 385.

85 Cf. AMU. N.167: 1751, Outubro, 12, Bahia. OFÍCIO: para o melhor aproveitamento das palmeiras do Brasil. Apud: ALMEIDA, Eduardo de Castro e. Inventário dos documentos relativos ao Brasil existentes no Archivo da Marinha e Ultramar de Lisboa, t.I, p.12-13; Cf. CASAL, Padre Manuel Aires de. Corografia brasílica, t.II, p.159; Cf. EMPERAIRE, Laure. Entre paus, palheiras e cipós, p.405, 416; Cf. SPIX, Johann Baptist von e MARTIUS Carl Friedrich Philipp von. Viagem pelo Brasil, t.II, p. 219-220, 274-278, 305, 342-343, 348, 356-357, 376, 378, 387, 395, 487-488, 547-551; T.III, p. 24-26, 30-31, 125-126, 150-151, 262, 369-370 e 385. 
tamanho das palmas, da flexibilidade e da resistência da palha. ${ }^{86}$ Da mesma mata que fornece o material de construção também proveem alimentos e remédios, sobressaindo-se a fartura advinda das espécies frutíferas. ${ }^{87}$

No grupo das espécies medicinais, destacam-se plantas conhecidas, principalmente, pelas populações aborígines da região norte do Brasil, cuja sabedoria é compartilhada com benzedores, curadores, parteiras e rezadores. São utilizadas para as mais diversas finalidades, desde aliviar males digestivos, dermatológicos, respiratórios, e até minimizar os efeitos de picadas peçonhentas. As cascas, folhas, flores e/ou inflorescências, frutas, raízes e sementes constituem a base do preparo de remédios caseiros. ${ }^{88} \mathrm{~A}$ prática de tal "ciência" não passava desapercebida nem para o colonizador nem para os viajantes europeus do século XIX, que tentavam, mediante o contato estabelecido com os nativos da terra, adquirir destreza na identificação e na manipulação dos segredos do mundo vegetal. ${ }^{89}$

No âmbito do pomar e do terreiro da roça, locais marcados pela diversidade e promiscuidade dos cultivos, evidenciam-se sobretudo as plantas alimentares e medicinais, destacando-se ainda espécies ornamentais, de caráter exótico, dentre elas: jasmineiros, laranjeiras e roseiras, ${ }^{90}$ além de exemplares ligados à "proteção" da moradia e/ou de seus habitantes, como o cipó-jiboia, o manacá, o pinhão-roxo, o tipi. ${ }^{91}$ Nos pomares, é comum a ocorrência de grandes fruteiras, que fornecem em certos pontos densas sombras, devido ao formato de suas copas. Nesse subespaço, costumam ser observados: abacateiros, anonas, apuruis, azeitonas-do-mato, bananeiras, biribazeiros, cafeeiros, caneleiras, goiabeiras, cajaranas, coqueiros, cupuaçus, frutas-pão, girus, graviolas, ingazeiras, jaqueiras, jambeiros, laranjeiras, limeiras, limoeiros, mangueiras, manjeriobas, mamoeiros, maracujazeiros, pupunheiras, tamarindeiros, tangerineiras, urucuzeiros. Nos domínios da horta, encontram-se os seguintes exemplares de plantas aromáticas, condimentares e medicinais: açafroa, agrião, alfavaca, alho, anador, arruda, boldo, capim-santo, carajiru,

86 Veja-se: COSTA, Eliza Lozano et al. Casa, p.233-241.

87 Veja-se: EMPERAIRE, Laure. Entre paus, palheiras e cipós, p.401 e 408-409.

88 Veja- se: EMPERAIRE, Laure. Entre paus, palheiras e cipós, p.400, 402, 404 e 408-412.

89 Cf. AHU. PERNAMBUCO-ACL-CU-015, Cx.163, D.11689: 1788, Maio, 8, Recife. OFÍCIO do [governador da capitania de Pernambuco], D. Tomás José de Melo, ao [secretário de estado da Marinha e Ultramar], Martinho de Melo e Castro, remetendo diversas amostras vegetais de uso medicinal, procedentes da Paraíba, e um abecedário das aplicações dessas plantas; Cf. CASAL, Manuel Aires de, Padre. Corografia brasílica, t.II, p.244-245 e 322; Cf. SAINT-HILAIRE. Auguste de. Viagem à província de São Paulo e resumo das viagens ao Brasil, Provincia Cisplatina e Missões do Paraguai, p.325 e 328-329; Cf. SPIX, Johann Baptist von e MARTIUS Carl Friedrich Philipp von. Viagem pelo Brasil, t.II, p.203-214 e 425-430; T.III. p.370-372.

90 Cf. SPIX, Johann Baptist von e MARTIUS Carl Friedrich Philipp von. Viagem pelo Brasil, t.I, p.145-146 e 147150.

91 Cf. EMPERAIRE, Laure. Entre paus, palheiras e cipós, p.415. 
carmelitana, cebola, cebolinha, chicória, cidreira, coentro, coramine, couve, elixir paregórico, erva-doce, eucalipe, gergelim, hortelãs, japana, macela (mansa e brava), malvarisco, manjiroba, mastruço, maxixe, melhoral, meru, patchuli, pimentas (malagueta, nativas e do-reino), pluma, quebra-pedra, rinchão, sabugueiro, sena, taioba, tomate, vassourinha, vinagre. ${ }^{92}$

Segundo a tradição vigente, observada por meio de conhecimento ancestral e transmissão de valores, a roça continua sendo constituída por diversos subespaços distintos, formal e funcionalmente complementares entre si, o que a torna versátil. No caso particular das roças, sabe-se que estavam voltadas para a prática do cultivo primitivo do solo, condição por demais evidenciada nas crônicas de época, que pouco se detinham nos subespaços desse conjunto, composto de casa, horta, jardim, pomar, mata, roçados e terreiro, além de criatórios e lugares apropriados para a localização de engenhocas destinadas ao processamento de algodão, cana-de-açúcar, mandioca e milho. ${ }^{93}$

Em suma, a roça é um complexo constituído por um amplo e rico repertório de espécies vegetais. A maneira como se encontra(va) disposta, segundo dados levantados, favorece a impressão de uma extensa mancha verde, fortalecida pela presença da mata. No universo dessa categoria tipológica, marcada pelo pragmatismo, os cultivos realizados permaneciam em completa sintonia com o suporte biofísico, as linhas de água, a ocorrência de solos férteis, a topografia, dentre outros recursos naturais. A adoção de princípios e regras tradicionais, referentes à escolha do sítio, à implantação dos edifícios e ao ordenamento das unidades produtivas, visava a proporcionar, além da produtividade, a maior interação dos proprietários rurais com os conjuntos construídos e a paisagem, como acontece até hoje. ${ }^{94}$

92 EMPERAIRE, Laure. Entre paus, palheiras e cipós, p.402 e 408-410.

93 Dentre as mercadorias produzidas, no mencionado domínio, durante os oitocentos, destacamos algumas, como açúcar gramixó (mascavo), alfenim, azeite (de-andiroba, copaíba, gergelim, mamona), borracha, cachaça, canela, carne seca, cascas de árvores, castanhas-da-terra, copal/resinas, doces de fruta (goiabada, marmelada, tamarinada), "drogas do sertão" (baunilha, cacau, cravo-da-índia, cravo-do-maranhão, gengibre, guaraná, noz-moscada, piaçava, raízes aromáticas, salsaparrilha, urucum), estopa, farinhas da terra (fubá de milho, de mandioca), goma, mel (melado), plantas medicinais (quina-do-campo), plumária de aves raras, polvilho, rapadura, talco, tapioca, toucinho. Nesse quadro, salientamos a quantidade de artigos provenientes da coleta vegetal, que eram regularmente transportados até os centros consumidores, sem maiores riscos de perda. Cf. SPIX, Johann Baptist von e MARTIUS, Carl Friedrich Philipp von. Viagem pelo Brasil, t.I, p.211; T.II, p.140-141, 194-195, 299, 312 e 547-551; T.III, p.25-26, 125-126, 369-370 e 385; LEITE, Padre Serafim. História da Companhia de Jesus no Brasil, t.IV, p.155-157.

94 LEMOS, Carlos A.C. Cozinhas, etc., p.35; MAWE, John. Viagens ao interior do Brasil principalmente aos distritos do ouro e dos diamantes, p.82-83. 